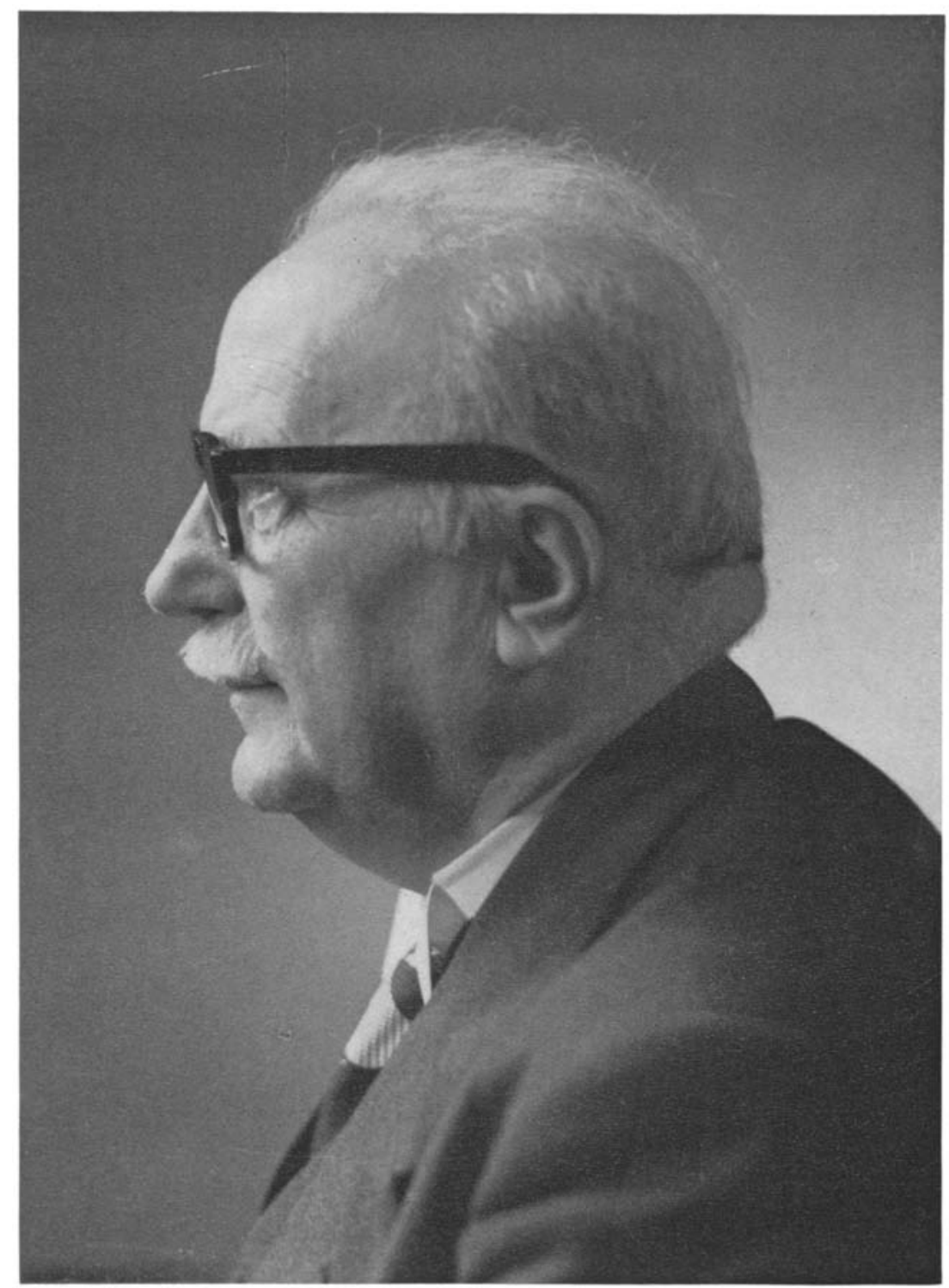

Prof. Dr. Paul van Oye 


\title{
In Memory of Professor Dr. Paul van Oye
}

\author{
(I886- I966)
}

\author{
F. EVENS
}

Professor van Oye came from a family of medical doctors from which originated several men of quality.

His grandfather, René van Oye was a physician at Torhout. He had a large medical practice which did nevertheless not keep him from serious scientific research. He had strong views on the natrual scientific character of medical science and put his ideas to the test in his daily practice which makes him in this respect a forerunner. (Elaut L.). In his “Mémoire sur 1'Anatomie et la Physiologie d'une Production confervoide particulière" published in 1843 he described the phenomenon of the swarmers of the algae. Dr. A. Schierbeek justly wrote about this publication: "I think to be permitted to state that the forming of swarmers was described in the same year by Unger and by R. van Oye, independently from one another."

In the social sector he strove purposefully after the material and intellectual development of his people and in his provincial town he founded the first agricultural college of Belgium.

The father of Paul van Oye, Dr. Eugeen van Oye was a well-known physician at Ostend, whom the Muse chose for a talented poet. He was the favourite pupil of Guido Gezelle who dedicated to him the beautiful poem "Die avond en die roze". Eugeen van Oye was a talented physician-artist who had a frequent correspondence with all artists of his time and in whose house many a circle of friends were welcomed.

It is at the seaside resort of Ostend, in the dunes and on the beach, near the breaking water of the North Sea, in the hospitable house of an original and broadminded father and with the scientific and artistic tradition of the family that young Paul van Oye grew up and was so to speak modelled. Young Paul van Oye certainly inherited talent but there is no doubt that those specific surroundings had a major influende upon the life, the ideas and the behaviour of the young man. 
Longing for the sea, the water, the far-away, the unfamiliar; generous and homely by nature, little conventional in his thinking and behaviour, yet always taking care not to offend a person in his conviction or feeling; scientifically inquisitive with vivid thoughts about new viewpoints or new research; punctual in an all-embracing activity, inspiring and stimulating his students, circumspect and yet optimistic; real flemish with a strong social feeling, firm but without extremism - that was Professor van Oye, the Professor who so often accompanied his students on Sunday study trips in the bleak winter months of the Second World War when shivering of cold with numb fingers he helped pull up the planctonnet while reciting poems or singing Bach cantata.

Young Paul van Oye received his secondary education at the Royal Atheneum at Ostend. This fact sufficiently proves how independent the van Oye family was in nearly medieval Catholic Flanders. The close friendship with Gezelle on the other hand shows a broad minded tolerance in the leading circle of the Flemish revival. At Ghent University where the language was exclusively French the young Flemish feeling student very soon came into contact with Professor Julius Mac Leod, founder of Dodonaea, leading botanist, influential scientist and militant Fleming, who put on van Oye an inefface 1 ble stamp of scientific accuracy and honesty and of social and cultural attachment to his people.

The lifelong attachment of Paul van Oye to Dodonaea and to the Biological Yearbook, which he was proud to see developing under his leadership every year, probably finds its origine in the influence of Mac Leod during his carefree youth. Paul van Oye was not the type of student that obediently attends lectures and hides at night in his ivory tower to assimilate the subject matter. No, he protested, he was one of the leaders in the fight for equal rights of the Flemish language at Ghent University and as the protesting youth of to-day young Paul van Oye was seen in the coffee houses and bars of Ghent, expressing hotly the new idea, standing on the tables. It is not amazing that the young student came into conflict with some French feeling professors. That the envy and the rancour would outlast more than 10 years and even a world war, is characteristic for the bitterness of the fight. After his doctorate in zoology obtained in 1911 van Oye started his medical studies. Although the study of medicine was in the line of family tradition, it appears to me that after the bitter experience the desire for an independent living urged him particularly to this study which was interrupted by the first World War. In 1915 we find the young biologist at Batavia (Dutch East Indies) as a biological assistant to the Marine Biological Laboratory and shortly afterwards as a lecturer to the college for medical assistants and lastly in 1918 as 
the Head of the laboratory for Inland Fishery at Tasikmalaya (Java).

Van Oye tries to find his way and works hard. This is testified by the numerous publications on different subjects: mathematical biology (in succession of his teacher J. Mac Leod); freshwater fish, sea fish, chaetognathes and the micro-organisms in the water. It is in the end the plancton that attracts him most and gradually his studies are concentrating on this subject. War circumstances and lack of libraries specialized in the subject hamper van Oye to go further in the direction of the traditional branches of systematics and floristics. In spite of this van Oye proceeds. He knows how to adapt himself (as he will prove later on in his life). He studies the relation between the external factors (salt percentage, temperature, speed of current, height above sea-level) and the few plancton groups of which he has the indispensable bibliographical data at his disposal. He studies the ecology of plancton at a moment that the idea itself is still developing.

Three studies of synthesis are of eminent importance because on the one hand they show for the first time that the qualitative and quantitative composition of plancton really is dependent on ecological factors, among which the alternation of wet and dry season in the tropics appears to be an important factor so far unknown and on the other hand because they represent a first highly valuable attempt to classify the waters according to geographical position, physical characteristics and salinity, used and elaborated later on by Redeke. After half a century of important scientific research it is still worth while to read the following three studies:

Einteilung der Binnengewässer Javas (1922)

Zur Biologie des Potamoplanktons auf Java (1922 en 1924)

Biologie et Ecologie du Phytoplancton d'un Lac tropical (1924)

As the Head of the Inland Fishery Laboratory of Tasikmalaya the culture of fish has his particular attention. Aware of the importance of the plancton for the culture of fish and with an extensive practical experience in the field, van Oye returns to Belgium. His return was no triumph, even far from it. He had left Tasikmalaya because his further career there appeared uncertain, which was the result of the rancour of one of his former professors from Ghent. He arrived in Belgium without any prospect to find employment, the more so, since his father had been stigmatized as a Flemish activist during the war and had been obliged in his old age to resume the streneous Doctor's life at Gistel near Ostend. But young van Oye was not discouraged. He went on with his studies of medicine while in the meantime he was looking for work. By some lucky chance he was in a position to visit Congo to investigate the problem of the culture of fish. This was the thing he wanted. He knew the problems, he knew the Netherlands East Indies and Congo offered him a unique opportunity 
to test his knowledge and experience to new but similar conditions. Though this first mission was for a short period (10 months) it was rather fruitful since less than three years later (1925), after obtaining the doctor's degree in medicine, he returned to Congo to introduce fish culture. He left by boat from Antwerp with aquaria full of living carps. The technical equipment to keep these carps alive was most primitive. Thanks to his untiring struggle and resourcefulness van Oye did succeed, after a streneous voyage of 42 days, to put his living carps into the water in the area round Stanleystad.

The new field of research appeared very promising and within a short time numerous contributions on plancton and particularly on algae were published. Apart from the numerous data on systematics and floristics which he succeeded to assemble, our attention should primarily concentrate on his studies on: "Le Potamoplancton du Ruki au Congo Belge et des pays chauds en général" (1926) et "Données concernant la distribution géograhpique des Algues au Congo Belge" (1927). In these studies he conclusively proves that also in Congo the periodicity of the plancton is related to the wet and dry season in the same way as on Java and that the geographical distribution of the algae in Congo is intimately linked with the existence of two geographial areas: the central and western drainage basin and the eastern mountain area.

On 27 october 1926 he was appointed professor to the State University of Ghent, at that time under the rule of the so-called Nolf Act, according to which the Flemish department of the State University was allowed to give two thirds of its lectures in the flemish language and one third in french wheras the rule for the French department was the reverse. The number of lectures and practica of the young professor was so large that hardly any spare time was left for scientific research work in the laboratory. Moreover the most elementary books and laboratory equipment were lacking. In spite of that at regular times studies were published either about data collected in the Dutch East Indies and Congo or about general subjects. From 1930 his activities as a research worker and as Head of the laboratory are in full swing again. The biogeography and ecology of plancton retain his special interest but his abundant task at the University proves an impediment for a thorough study of the numerous plancton groups. $\mathrm{He}$ is obliged to limit himself. In his choice of the plancton groups which he intends to study viz. the Desmidiaceae, the Rhizopoda and the Rotifera we probably find an expression of his artistic feelings.

It would take us too far to trace how many new species van Oye has described and how many new locations he has noted for the species of these groups in Belgium.

VI 
For him this was not the most important. The punctual and regular research extended over years, his particular faculty for observation and his indefatigable perseverance in the study of the above plancton groups together with the study of the evolution of some ecological factors, have lead him to divide Belgium into biogeographical provinces where the waters show similar ecological conditions and so contain similar plancton species. On the other hand he could prove that waters in biological equilibrium show fluctuations of the $\mathrm{pH}$ over the years never surpassing the value of one $\mathrm{pH}$ unit.

Gradually new material was investigated from Iceland, Congo, Java, Venezuela, New Zealand which lead to a general synthesis of the geographical distribution of some species.

In addition we mention former studies on the origin of lime formations in the Ardennes.

There is not the slightest doubt that the contribution of van Oye in the field of biogeography and the ecology of plancton is of the utmost importance for Belgium because as a matter of fact he introduced and developed ecology but his publications also received wide international recognition. Nevertheless we would be unjust to van Oye by mentioning only his personal studies. Van Oye succeeded with his students to arouse enthusiasm for biology in general and for Hydrobiology in particular. The numerous students amounting to over 20 , he has trained were given much of his time and much of his knowledge and experience. Each paper published by the student contained a great deal of work from the Professor, although sometime the latter was not even mentioned as co-author. Each paper was read, examined and discussed at the laboratory, but quite often at home until late at night.

He hardly ever failed to be present when samples were taken wherever in Belgium.

There are many women that help and support their husband in his work. Many of them even make sacrifices, but I know very few women like Mrs. van Oye who dedicated her whole life to the work of her husband, to the educational and social task he had to perform. If van Oye was able to work so hard, to train so many students and to help so many in distress, it was for a great deal thanks to the gentle, loving and cheerful Mrs. van Oye, to her help, her devotion and even her selfdenial.

The second World War brought misery and trouble everywhere. The van Oye family too was not spared. Up to three times Professor van Oye was fetched and taken prisoner, let alone the numerous difficulties involved that preceded and followed. Even in the most difficult circumstances van Oye remained steady, supported by Mrs. van Oye who was firm and prepared for everything. 
Was van Oye proud of himself after the war? Did he take advantage by extending his sphere of influence or did he even make capital out of his suffering? No, van Oye remained the man he had been, dedicated to his scientific work. With new zeal work was resumed.

Hydrobiologia was born. The extensive experience van Oye had gathered since 1937 as the Chief Editor of the Biological Yearbook Dodonaea could be used for this international periodical. The result was bound to come. Hydrobiologia became "the" international periodical for hydrobiology.

In 1948 van Oye was appointed chairman of the department of Sciences of the Royal Flemish Academy of Sciences, Litterature and Arts of Belgium.

But the laboratory research went on: Desmidiaceae, Rotifera, Rhizopoda, Waterproblem, Ecology, Biogeography, culminating, so to speak, in the successful Eleventh International Congress for theoretical and applied Limnology organised at Ghent by van Oye as the Chairman.

He was appointed Vice-chairman of the Board of Governors of the State University of Belgian Congo and Ruanda Urundi.

At the age of 70 he departed again for the Congo where he had stayed 35 years before and apart from his official assignment he succeeded in finding the time and the energy to collect plancton samples from the most different places.

And yet van Oye has changed. Gradually more studies are published on personalities and on the history of the biology. One could say that he is preparing his retirement which is granted to him on August 25th, 1956.

For van Oye this retirement does not mean rest; it is an adaptation, a development of a sphere of interest of which the germ was present already since a long time. He becomes the Chairman of "Higher Education for the People" and with renewed strength he devotes his busy days to the study of the history of the biology in Belgium.

It is his driving power which leads on the one hand to the foundation of "Zuid-Ge-Wi-Na" (South Netherlands Society for the History of Medicine, Mathematics and Physics) with the periodical Scientiarum Historia and on the other hand to the foundation within the Ghent University of a museum for the history of sciences. Herewith a long cherished wish of his deceased friend Professor A. J. J. van de Velde had come true.

By thorough personal investigation he succeeds to describe and revive the spirit and personality of his biologists in numerous publications. The list of publications shows that his former professor and friend J. Mac Leod was not forgotten.

Lastly his general study on the "History of the development of 
hydrobiology in Belgium" bears testimony to his objectiveness and humility, the undeniable marks of the wisdom of the old Professor.

In July 1969 shortly before his illness Paul an Oye lived to see a last great triumph: his father Eugeen van Oye was not only officially rehabilitated but a statue was erected for him at Gistel near Ostend where a large crowd paid tribute to the van Oye family. Paul van Oye still looked a healthy man, full of life and yet it was his last journey. In september he was urgently taken to the hospital of the Ghent University for a surgical operation. His optimism did not leave him, the more so because he was allowed to leave the hospital after a few days. Alas his days were counted inexorably. He died on October 11th 1969. His life was a magnificient illustration of the motto he had chosen when he was a young man "Arbeiten und nicht Verzweifeln".

ELAUT, L. - 1964 - René van Oye en het streven naar een natuurwetenschappeliike geneeskunde in het partikularistische West Vlaanderen, tijdens de eerste decenniën van de Belgische onafhankelijkheid. Biol. Faarb. Dodonaza, 32: 378-390.

Evens, F. - 1943 - Korte schets der geschiedenis der wierkunde in België. Biol. Faarb. Dodonaea, 10: 77-87.

Evens, F. - 1944 - Geschiedenis der Algologie in België. Verh. Koninkl. Vlaamse Acad. Wetensch. Lett. en Sch.Kunst. België, Kl. Wetensch. 6, 10: 203, 13 port.

Luyckx, T. - 1967 - De tweetalige zg. Nolf Universiteit te Gent (1923-1930). in: Hoofdmomenten uit de ontwikkeling van de Gentse Rijksuniversiteit (1817-1967). Extra Nummer van de De Brug, Rijksuniversiteit Gent, 1967: 93-117.

LuYckx, T. - 1957 - Gedenkboek van de Rijksuniversiteit te Gent. $\mathrm{Na}$ een kwarteeuw vervlaamsing (1930-31 - 1955-56). Rijksuniversiteit Gent, 1957, p. 441.

SCHIERBEEK, A. - 1936 - Voortplanting der Algen en de Overgang van Planten in Dieren (1843). Natuur en Mens, 1: 18-19.

Symoens, J. J. - 1963 - Un siècle de recherches belges sur la floristique et l'écologie des Algues. Bull. Soc. Roy. Bot. Belg. 95: 153-191, 1 carte.

VAN OYE, P. - 1960 - Curriculum vitae en lijst publikaties in: Rijksuniversiteit te Gent. Liber Memorialis (1913-1960) Deel IV. Faculteit der Wetenschappen. 1960: 164-174.

VAN Oye, P. - 1967 - Geschiedenis van de ontwikkeling der Hydrobiologie in België. Verh. Koninkl. Vlaamse Acad. Wetensch. Lett. Sch. Kunst. België, kl. Wetensch. 29, 93: 174, 18 portr. 


\section{Curriculum Vitae}

Paul, Herman, Gustave van Oye was born at Ostend on August 24th 1886. Secondary Education: Royal Atheneum of Ostend. Higher Education: State University at Ghent and School for tropical medicine, Brussels.

Studies Zoology at Ghent and takes the doctor's degree in zoology with Professor F. Platteau on July 21st, 1911. (Thesis: Experimental studies on the behaviour of the flatworms).

Assistant with Professor Lebrun.

Studies medicine at Ghent from 1912.

Soupart Price for studies with A. Minne about bacteriological control with surgical operations.

Secretary of the Board of Editors of "Natuur en Wetenschap" 1914. Studies of Medicine interrupted by the first World War 1914-1918. Appointed biological assistant to the Marine Biological Laboratory at Batavia, Dutch East Indies.

Member Board of Editors "Tropische Natuur" 1915.

Lecturer in biology and comparative anatomy at the Training School for local physicians at Batavia in 1916.

Appointed Head of the Laboratory for Inland Fisheries at Tasikmalaya in 1918.

Return form the Dutch East Indies to Belgium in 1922.

Resumes studies of medicine at Ghent University.

Entrusted with special assigment to study the possibility of the fish culture in Congo.

Doctor of Medecine on July 19th, 1924 at Ghent.

Doctor of tropical Medicine on February 7th, 1925.

Departs on march 10th, 1925 as laboratory physician with special assignment to introduce fish culture in Congo.

Appointed on october 27th, 1926 as a professor at the State University at Ghent for the following subjects:

1926: Zoological systematics and zoological geography (doctor's degree in zoology).

1927: comparative anatomy (bachelor's degree)

botanical geography (doctor's degree botany)

botanical geography and ethnographicalgeography (with practica) (Master's degree)

botanical geography (Doctor's degree Natural Sciences) 
ethnography (Business School attached to the Faculty of Law) 1928: General biology and general physiology (Higher Education for Pedagogy)

In 1932 the subjects of Professor van Oye were thus altered:

a) Masters degree zoological sciences The systematic zoology (not included zoological paleontology). The animal ecology included the zoogeography.

b) Teacher training for the Senior High School. The particular methodology of the zoology

c) Master's degree in the geographical sciences:

The geography of animals and plants.

Head Editor of the "Biologisch Jaarboek" from 1927-1969.

Co-founder and Vice-chairman (1929) of the "Internationale Vereinigung für theoretische und angewandte Limnologie".

Member of the "Commissie voor Biosociologie en Veenonderzoek van de Nederlandsche botanische vereniging" 1933-1935 en 19411943.

Appointed as a full Professor from October 1st, 1936 (K.B. van 4 november 1937).

Chairman of "Dodonaea" 1937-1969.

Vice-chairman (mandate of three years 1939) and chairman (mandate of two years 1941) of the "Société Royale de Botanique de Belgique".

Member of the Royal Flemisch Academy of Sciences, Literature and Arts of Belgium (1939).

Member of the Board for the History of the sciences of the Royal Flemish Academy for Sciences, Litterature and Arts of Belgium (1941).

Chairman of the Flemish Scientific Foundation (1941).

Member of the 6th Commission Botany and Paleobotany of the National Fund for Scientific Research (1942).

Secretary to the Pedagogical Institute of the State University of Ghent (1945).

Entrusted in 1947 with the practica of the biology, especially with pedagogical application. (master's degree pedagogical sciences).

Founder (1947), Head Editor of Hydrobiologia - Acta hydrobiologica, hydrographica et protistologica (34 volumes).

Head Editor for Belgium of Oosthoek's encyclopaedia (fourth edition) Appointed in 1948 Director of the department of Sciences of the Royal Academy of Sciences, Literature and Arts of Belgium.

Chairman of the Eleventh International Congress for the theoretical and applied Limnology at Ghent.

Appointed in 1955 second Vice-chairman and in 1957 Vice-chairman 
ot the Board of Governors of the State University of the Belgian Congo and Ruanda Urundi at Elisabethstad.

Granted retirement on august 25th 1956.

Member of the High Council for Education in the Belgian Congo and Ruanda Urundi (1958).

Co-founder of the "World Scademy of Art and Science (WAAS) 1960.

Co-founder and chairman of the "Zuid-Nederlands genootschap voor de geschiedenis der Geneeskunde, Wiskunde en Natuurwetenschappen", (Zuid Gewina) 1960.

Professor van Oye died on October 11th 1969 at Ghent's University hospital. 